\title{
The genetics of distyly and homostyly in Turnera ulmifolia L. (Turneraceae)
}

\author{
Joel S. Shore and \\ Spencer C. H. Barrett
}

\author{
Department of Botany, University of Toronto, Toronto, \\ Ontario, Canada M5S 1 Al.
}

Turnera ulmifolia L. is a polymorphic complex of diploid, tetraploid and hexaploid varieties. Diploids and tetraploids are distylous and hexaploids homostylous. A controlled crossing programme demonstrated that in diploids distyly is controlled by a single locus with two alleles. Long-styled plants are ss and short-styled plants can be either Ss or SS. In tetraploids a similar pattern occurs with short-styled plants usually Ssss and long-styled plants ssss. Tetrasomic inheritance was demonstrated by crosses with a SSss genotype synthesised by colchicine doubling. Double reduction could not be detected at the distyly locus. No significant deviation from a 1:1 morph ratio was observed in surveys of nine natural populations and progeny tests of 21 open-pollinated familes from Brazil. Crosses between distylous and homostylous populations were undertaken to determine the inheritance of homostyly. The results were consistent with a model of supergene control. Clear segregation of phenotypes was observed in the $F_{1}$, and the dominance relationships $S>h>s$, where $h$ is an allele that determines homostyly, were obtained.

\section{INTRODUCTION}

Distyly occurs in at least 23 flowering plant families (Ganders, 1979) and has undoubtedly evolved several times. The inheritance of distyly has been determined for species in 11 genera from nine families (Ornduff, 1979). The syndrome of floral characters, by which the long- and short-styled morphs differ, is inherited as if controlled by a single gene locus with two alleles. Except for two genera where the dominance relationships are reversed (Baker, 1966; Ornduff, 1979), the longstyled morph is homozygous (ss) while the shortstyled morph is heterozygous $(S s)$. Evidence from the Primulaceae (Ernst 1955), and the Plumbaginaceae (Baker, 1966) suggests that distyly is controlled by a series of tightly linked genes comprising a supergene. Aberrant forms termed homostyles, with anthers and stigmas at the same level within a flower, are interpreted as recombinant phenotypes that arise by crossing over within the supergene. A recombination event resulting in homostyly has, however, never been detected in heterostylous species (Charlesworth and Charlesworth, 1979 $a$ ). In addition, apart from a few notable exceptions (Crosby, 1949; Ernst, 1955; Ganders, 1975), homostyles are rarely observed in distylous populations, although relatives of heterostylous taxa are frequently homostylous.
Turnera ulmifolia L. is a polymorphic assemblage of perennial weeds native throughout the Neotropics. Urban (1883) deseribed 12 varieties within the complex, six of which are distylous and the remainder homostylous. Barrett (1978) described the floral biology and breeding systems of four varieties within the complex, and a recent survey of chromosome numbers in 43 populations of T. ulmifolia (Shore and Barrett, 1985; and unpublished data) revealed a correlation between breeding system and ploidal level. All distylous populations are diploid or tetraploid, whereas homostylous populations are hexaploid. Here we investigate the genetics of breeding system variation in the T. ulmifolia complex. Specifically we: (1) determine the inheritance of distyly in diploids and tetraploids; (2) provide data on morph ratios and segregation from natural populations; (3) determine the inheritance of homostyly and discuss evidence for supergene control of distyly.

\section{MATERIALS AND METHODS}

A crossing programme was undertaken on glasshouse grown plants raised from seed collections or cuttings obtained from natural populations. Table 1 gives the locality, chromosome number and varietal status of accessions used in the study. 
Table 1 Varietal status, ploidal level, and locality of Turnera ulmifolia accessions used in experimental studies $(X=5)$

\begin{tabular}{lllll}
\hline & & Ploidal & & \\
Population & Variety & level & Locality & Collection No. \\
\hline 11 & intermedia & $2 X$ & Barreirinhas, Brazil & Barrett 1128 \\
13 & intermedia & $2 X$ & Caracas, Venezuela & Barrett 1125 \\
16 & intermedia & $2 X$ & Managua, Niearagua & Barrett 1342 \\
I24 & intermedia & $4 X$ & St. Cristohal, 1)ominican Rep. & Barrett and Shore 1364 \\
132 & intermedia & $2 X$ & Arco Verde, Brazil & Barrett and Shore 1374 \\
E5 & elegans & $4 X$ & Crato, Brazil & Barrett 222 \\
E11 & elegans & $4 X$ & Salgueiro, Brazil & Barrett and Shore 1372 \\
A5 & angustifolia & $6 X$ & Ochos Rios, Jamaica & Barrett 1253 \\
A11 & angustifolia & $6 X$ & 1)ragons Bay, Jamaica & Barrett 1259 \\
A17 & angustifolia & $6 X$ & Pelican Lake, Grand Bahama & Correll 40638 \\
O1 & orientalis & $6 X$ & Corrientes, Argentina & Arbo 1538 \\
V1 & velutina & $6 X$ & Tuxtla Gutierrez, Mexico & Koch \& Fryxell 78341 \\
\hline
\end{tabular}

Each individual was given a code indicating its accession, or family if applicable, followed by a numeric value specifying the particular individual within the accession, and by a letter indicating its phenotype ( $\mathrm{L}=$ long-styled, $\mathrm{S}=$ short-styled, $\mathrm{H}=$ homostyled). All pollinations were performed in a pollinator-free glasshouse using fine forceps. Flowers were emasculated prior to cross-pollination. Pollinated flowers were individually marked and maturing capsules were wrapped with parafilm to prevent loss of seeds during dehiscence. As distylous members of the complex are strongly self-incompatible two different methods were used to obtain seeds from self- or intra-morph crosses: (1) flower buds were opened one day prior to anthesis and pollinated from an open flower of the same individual (bud-selfing), (2) plants were screened for the presence of a weakened incompatibility reaction (pseudo-compatibility) and those yielding more than three seeds per pollination were later used in the crossing programme. Progenies obtained from crosses were grown to flowering in individual pots.

To investigate the inheritance of distyly at diploid and tetraploid levels accessions comprising different varieties were employed (table 1). Reciprocal crosses were generally performed and the results pooled. Preliminary results suggested that short-styled morphs were of genotype $S s$. To detect the occurrence of $S S$ genotypes, 19 shortstyled progeny derived from the self of $132-1$ S were selfed and at least 17 progeny from each family were grown to flowering and scored for floral morph. To investigate the possibility of tetrasomic inheritance and double reduction, the chromosome number of seedlings derived from the cross I32-1S $\times$ I1-10L, was doubled. A drop of $0 \cdot 1$ per cent colchicine applied to cotyledons resulted in the recovery of several tetraploid plants and a long- and a short-styled plant were selected for reciprocal crosses. To determine the inheritance of homostyly, three homostylous varieties, from five accessions of $T$. ulmifolia, were croseed to diploid long- and short-styled plants of known genotype.

To examine the equilibrium frequency in $T$. ulmifolia we extend the morph frequency data of Barrett (1978) by sampling a total of 1211 plants from nine natural populations of the tetraploid $T$. ulmifolia var. elegans in N.E. Brazil. Random or complete samples of populations were taken with at least 90 plants sampled per population. Further, progeny tests of 21 open-pollinated families, collected from population E11 in Brazil were performed to test for heterogeneity among families and among maternal morphs. On average 62 progeny were scored for each family.

All goodness-of-fit and heterogeneity tests were performed using the $G$ statistic (Sokal and Rohlf, 1981).

\section{RESULTS}

Neither of the two methods employed to obtain seed from selfing long- or short-styled plants was completely successful. Bud-selfing in T. ulmifolia results in seed set more often in short- than longstyled individuals; only one of many long-styled plants yielded seed. In both morphs the yield of seed from bud-selfing is less than 75 per cent of that from legitimate pollinations. Screening plants for pseudo-compatibility resulted in the recovery of a few individuals that produced sufficient seed on self-pollination to be useful for genetic study. Two plants were identified among diploids (I3I1$3 \mathrm{~L}$ and $\mathrm{I32}-\mathrm{SS}$ ) and two among tetraploids (E5-1 L and E5-10S). Progeny (>80 per cross) derived by selfing or crossing plants E5-1L and E5-10S were 
screened for self-compatibility. Six progeny yielded sufficient seed for further study.

\section{(i) Inheritance of distyly in diploids}

The inheritance of distyly in diploid T. ulmifolia var. intermedia was determined using three longand six short-styled plants, from four different accessions, and one long-styled plant (13I1-3L),

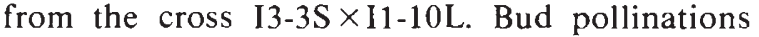
were used for all illegitimate crosses except those involving individuals I3I1-3L and I32-1S which yielded sufficient seed on selfing. The data presented in table 2 are consistent with the common

Table 2 Style morphs in progeny of crosses of Turnera ulmifolia var. intermedia $(2 n=10)$

\begin{tabular}{|c|c|c|c|c|}
\hline \multirow[b]{2}{*}{ Cross } & \multicolumn{2}{|c|}{$\begin{array}{c}\text { Style morphs of } \\
\text { progeny }\end{array}$} & \multirow[b]{2}{*}{$G$} & \multirow[b]{2}{*}{$P$} \\
\hline & Long & Short & & \\
\hline \multicolumn{5}{|c|}{ (a) Legitimate crosses } \\
\hline $16-12 \mathrm{~L} \times 16-19 \mathrm{~S}$ & 34 & 58 & $6 \cdot 33$ & $0 \cdot 01$ \\
\hline $16-12 \mathrm{~L} \times 16-31 \mathrm{~S}$ & 65 & 53 & $1 \cdot 22$ & $0 \cdot 27$ \\
\hline $16-12 \mathrm{~L} \times 13-3 \mathrm{~S}$ & 90 & 78 & $0 \cdot 86$ & $0 \cdot 36$ \\
\hline $13-3 \mathrm{~S} \times 13-4 \mathrm{~L}$ & 16 & 23 & $1 \cdot 26$ & $0 \cdot 26$ \\
\hline $\mathrm{I} 3-24 \mathrm{~S} \times \mathrm{I} 3-4 \mathrm{~L}$ & 9 & 9 & $0 \cdot 00$ & - \\
\hline $11-2 \mathrm{~S} \times 11-10 \mathrm{~L}$ & 26 & 18 & $1 \cdot 46$ & $0 \cdot 23$ \\
\hline \multirow{2}{*}{\multicolumn{2}{|c|}{$\begin{array}{l}\text { Deviation from } 1: 1 \\
\text { Heterogeneity }\end{array}$}} & \multirow{2}{*}{\multicolumn{2}{|c|}{$\begin{array}{l}G=0.002, P=0.96 \\
G=11 \cdot 138, P=0.05\end{array}$}} & \\
\hline & & & & \\
\hline \multicolumn{5}{|c|}{ (b) Illegitimate crosses of the short-styled morph } \\
\hline $16-19 S \times 16-31 S$ & 4 & 29 & $3 \cdot 40$ & 0.07 \\
\hline 16-19S selfed & 3 & 15 & 0.73 & $0 \cdot 39$ \\
\hline I6-31S selfed & 5 & 18 & $0 \cdot 13$ & 0.71 \\
\hline I3-24S selfed & 5 & 13 & 0.07 & 0.79 \\
\hline 13-3S selfed & 21 & 52 & 0.54 & 0.46 \\
\hline I32-1S selfed & 33 & 109 & 0.24 & 0.63 \\
\hline \multicolumn{5}{|c|}{ Deviation from $1: 3 \quad G=0.58, P=0.45$} \\
\hline Heterogeneity & \multicolumn{3}{|c|}{$G=4.52, P=0.50$} & \\
\hline \multicolumn{5}{|c|}{ (c) Illegitimate crosses of the long-styled morph } \\
\hline $16-12 \mathrm{~L}$ selfed & 52 & 0 & - & - \\
\hline $1311-3 \mathrm{~L}$ selfed & 156 & 0 & - & - \\
\hline
\end{tabular}

genetic model of the inheritance of distyly. Shortstyled plants are heterozygous $(S s)$, yielding both morphs on selfing, and long-styled plants are homozygous $(s s)$ with only long-styled plants in selfed progeny. Heterogeneity was apparent among legitimate crosses. This was largely the result of the cross (I6-12L $\times$ I6-19S); the only example showing heterogeneity among reciprocals. When the short-styled morph was used as the pollen parent a large excess of short-styled progeny was observed. Further we note that all crosses involving plant I6-19S yielded an excess of short-styled plants.
Four of 19 short-styled plants, derived by selfing plant I32-1S, yielded no long-styled progeny upon selfing. At least 34 selfed progeny were scored for each of these four plants. The probability of observing no long-styled plants among the progeny of a heterozygous parent for a sample size of 34 is less than $6 \times 10^{-5}$. Hence these individuals are likely to be short-styled plants of genotype $S S$. Among the segregating progenies, 105 long-styled and 326 short-styled plants were obtained and no deviation from $1: 3$ or heterogeneity, was observed $\left(G_{\mathrm{dev}}=0.09, P=0.76 ; G_{\mathrm{het}}=17.8, P=0.22\right)$. The occurrence of four non-segregating plants as well as the absence of a deficiency in short-styled progeny from selfs of short-styled plants indicates that $S S$ genotypes are viable.

\section{(ii) Inheritance of distyly in tetraploids}

At the tetraploid level plants from two accessions were used, one each from vars. elegans and intermedia. Bud-selfing was employed for individual I24-1S only. All other plants were selfed. Individuals SS3S and SS77S are self-fertile sibs obtained by selfing E5-10S and screening several of its progeny for pseudo-compatibility. Plants SL34S and SL36L were similarly obtained from the cross E5-10S $\times$ E5-1L and plants LL61L and LL51L from the self of E5-1L. Data in table 3 indicate that short-styled plants are heterozygous and long-styled plants are homozygous. Aberrant ratios were obtained in four crosses. The parental short-styled plant E5-10S yielded an extreme deficiency of short-styled progeny on selfing, as did two of its three progeny (SS77S and SL34S).

To account for the aberrant ratios from these three selfs, three models with different expectations were investigated. Since the crosses gave homogeneous segregations $(G=0.58, \quad P>0.5)$ results were pooled, giving a ratio of 1 long: $1 \cdot 23$ short. The models evaluated were: (1) a model assuming a maximum amount of double reduction, corresponding to random chromatid segregation (Allard, 1960), with an expectation of 1 long: $2 \cdot 48$ short $(G=52 \cdot 7, P<0 \cdot 001)$; (2) a model assuming lethality of zygotes containing more than one $S$ allele giving an expectation of 1 long: 2 short ( $G=$ 25.8, $P<0 \cdot 001$ ); (3) a model assuming both a maximum amount of double reduction and lethality of zygotes carrying more than one $S$ allele, with an expectation of 1 long: 1.6 short $(G=7 \cdot 72$, $P<0 \cdot 01)$. None of the models accounts for the extreme deficiency of short-styled plants, but the third comes closest to the observed ratio. Evidence reviewed below, however, indicates that double 
Table 3 Style morphs in progeny of crosses of Turnera ulmifolia vars. elegans and intermedia $(2 n-20)$

\begin{tabular}{|c|c|c|c|c|}
\hline \multirow[b]{2}{*}{ Cross } & \multicolumn{3}{|c|}{$\begin{array}{c}\text { Style morphs of } \\
\text { progeny }\end{array}$} & \multirow[b]{2}{*}{$P$} \\
\hline & Long & Short & $G$ & \\
\hline \multicolumn{5}{|c|}{ (a) Legitimate crosses } \\
\hline E5-1L $\times E 5-10 \mathrm{~S}$ & 91 & 76 & $1 \cdot 35$ & $0 \cdot 25$ \\
\hline $124-3 \mathrm{~L} \times \mathrm{E}, 5-10 \mathrm{~S}$ & 71 & 96 & $3 \cdot 76$ & $0 \cdot 05$ \\
\hline \multicolumn{4}{|c|}{ Deviation from $1: 1 \quad G=0.30, P=0.58$} & \\
\hline Heterogeneity & \multicolumn{3}{|c|}{$G=4.81, P=0.03$} & \\
\hline \multicolumn{5}{|c|}{ (b) Illegitimate crosses of the short-styled morph } \\
\hline $124.1 \mathrm{~S}$ selfed & 8 & 31 & $0 \cdot 44$ & $0 \cdot 51$ \\
\hline E5-10S selfed & 79 & 100 & $30 \cdot 89$ & $<0 \cdot 001$ \\
\hline SS3S selfed & 29 & 66 & 1.48 & $0 \cdot 22$ \\
\hline SS77S selfed & 56 & 61 & $28 \cdot 38$ & $<0.001$ \\
\hline SL34S selfed & 67 & 87 & 24.94 & $<0 \cdot 001$ \\
\hline \multirow{2}{*}{$\begin{array}{l}\text { Deviation fron } \\
\text { Heterogeneity }\end{array}$} & \multicolumn{3}{|c|}{$1: 3 \quad G=70.90, P<0.001$} & \\
\hline & \multicolumn{3}{|c|}{$G=15 \cdot 23, P=0 \cdot 004$} & \\
\hline \multicolumn{5}{|c|}{ (c) Illegitimate crosses of the long-styled morph } \\
\hline E5-1L selfed & 130 & 0 & - & - \\
\hline SL36L selfed & 147 & 0 & - & - \\
\hline LL61L selfed & 14 & 0 & - &.-- \\
\hline LL51L selfed & 6 & 0 & - & - \\
\hline \multicolumn{5}{|c|}{ (d) Legitimate cross of synthetic tetraploids } \\
\hline \multicolumn{2}{|c|}{ SNIS $\times$ LN1L 35} & 208 & - & -- \\
\hline \multicolumn{2}{|c|}{ Deviation from $1: 5$} & $0.93, P$ & $0 \cdot 33$ & \\
\hline
\end{tabular}

reduction may not occur at the distyly locus and hence the model may be inappropriate.

The synthetic tetraploids produced by somatic chromosome doubling had genotypes SSss (shortstyled) and ssss (long-styled). On crossing, the progeny showed no deviation from the expected 5 short: 1 long tetrasomic ratio (table $3(\mathrm{~d})$ ). A maximum likelihood estimate and standard error of the double reduction parameter $a$ was obtained jointly from these data and the pooled data from open-pollinated families of var. elegans (table 4). The estimation procedure yielded a value not significantly different from zero $(a=-0.045$, s.e. $=$ $0.044)$. Hence double reduction could not be detected at the distyly locus.

Style morph frequencies in natural populations of var. elegans in Brazil were homogeneous $\left(G_{\text {het }}=\right.$ $7.23, P=0.51)$ and reveal no significant deviation from $1: 1$ expectation $\left(G_{\mathrm{dev}}=0.07, P=0.79\right)$. The 21 open-pollinated families sampled from a natural population in Brazil (E11) of var. elegans $(2 n=20)$ provided no evidence of deviation from $1: 1$ expectation or heterogeneity among morphs or families within morphs (table 4).

\section{(iii) The inheritance of homostyly}

All $F_{1}$ progeny obtained from crosses between homostylous hexaploids and distylous diploids
Table 4 Style morphs in progeny of open-pollinated families of Turnera ulmifolia var. elegans $(2 n=20)$ from Brazilian population (E11)

\begin{tabular}{|c|c|c|c|c|}
\hline \multirow[b]{2}{*}{ Family } & \multicolumn{4}{|c|}{ Style morphs of progeny } \\
\hline & Long & \multicolumn{3}{|c|}{ Short } \\
\hline S1 & 39 & 43 & & \\
\hline S2 & 12 & 7 & & \\
\hline$\$ 3$ & 25 & 27 & & \\
\hline S4 & 10 & 15 & & \\
\hline S5 & 39 & 34 & & \\
\hline S6 & 29 & 22 & & \\
\hline S7 & 6 & 8 & & \\
\hline S8 & 10 & 9 & & \\
\hline S9 & 23 & 27 & & \\
\hline S10 & 29 & 23 & & \\
\hline S11 & 49 & 52 & & \\
\hline $\mathrm{Ll}$ & 1 & 1 & & \\
\hline L2 & 63 & 69 & & \\
\hline L3 & 46 & 49 & & \\
\hline L4 & 38 & 42 & & \\
\hline L5 & 35 & 30 & & \\
\hline L6 & 9 & 16 & & \\
\hline L7 & 8 & 14 & & \\
\hline L8 & 57 & 63 & & \\
\hline L9 & 39 & 35 & & \\
\hline \multirow[t]{2}{*}{ L10 } & 71 & 72 & & \\
\hline & & $\mathrm{df}$ & $G$ & $P$ \\
\hline \multicolumn{2}{|c|}{ Deviation from $1: 1$} & 1 & $0 \cdot 31$ & 0.58 \\
\hline \multicolumn{2}{|c|}{ Between morph heterogeneity } & 1 & 0.48 & 0.49 \\
\hline \multicolumn{2}{|c|}{ Between family heterogeneity } & 19 & $9 \cdot 68$ & 0.94 \\
\hline
\end{tabular}

were highly sterile. Sterility precluded the possibility of examing further generations. However, clear floral dimorphism was evident among progenies (fig. 1(a), (b)), despite morphological divergence and sterility barriers among the diploid and hexaploid varieties. In each of the three homostylous varieties that were examined, no long-styled plants were obtained in crosses. However, crosses that involved short-styled plants always segregated both short-styled plants and homostylous plants at equal frequencies (table 5). On the basis of these patterns of segregation an apparent homostyle allele $(h)$, which is dominant to the long-styled allele $(s)$, but recessive to the short-styled allele $(S)$, governs the homostylous phenotype in $T$. ulmifolia.

All homostyles of $T$. ulmifolia that we have examined exhibit the floral phenotype of a longhomostyle, with long styles and long-level anthers. However, considerable variation occurs in the relative lengths of reproductive organs among populations, with some displaying a considerable degree of herkogamy. Further details on the nature of the variation and its genetic basis will be presented elsewhere. 


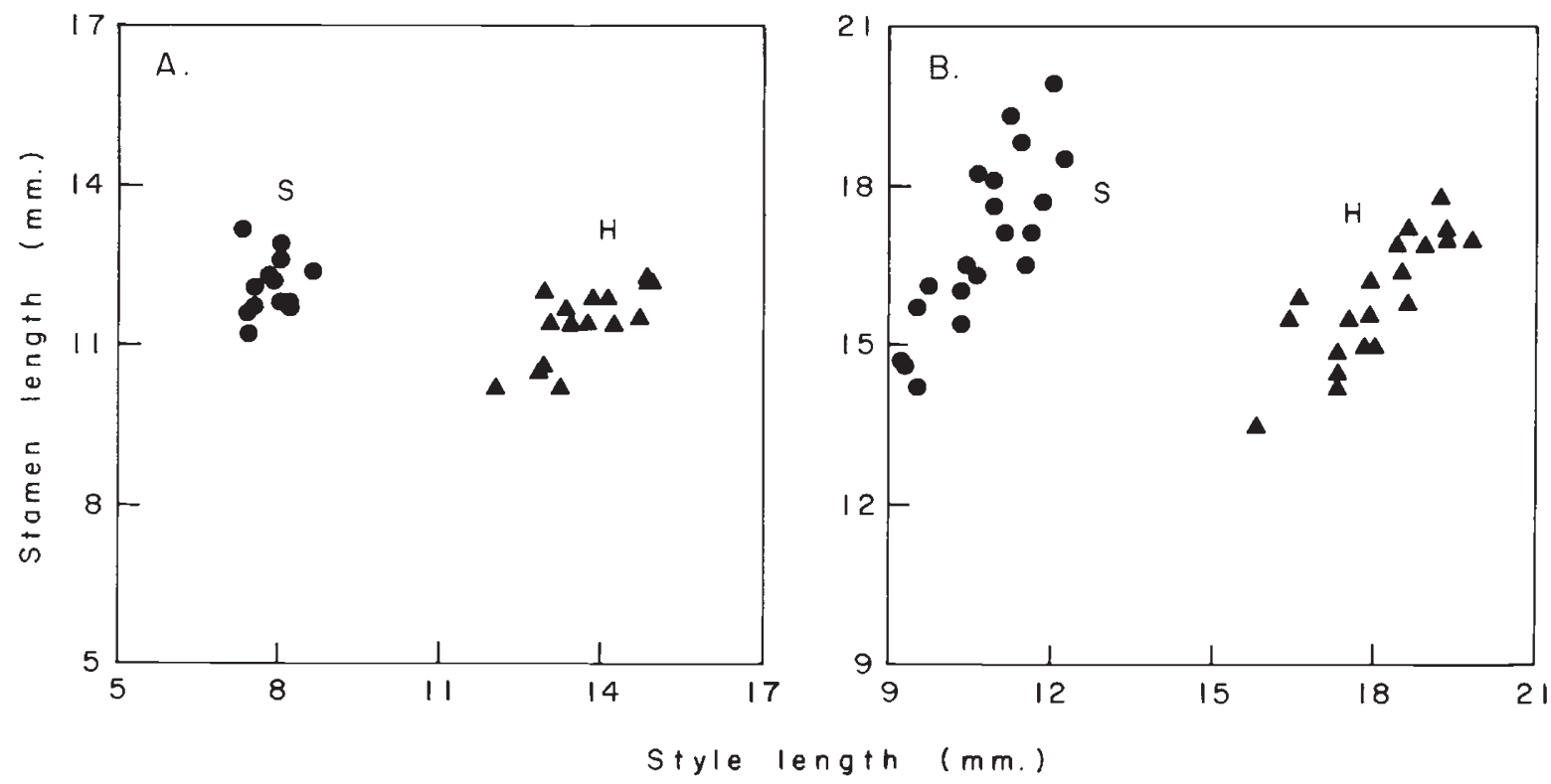

Figure 1 Distribution of floral phenotypes in crosses between distylous and homostylous populations of Turnera ulmifolia (a) O1-21 H $\times$ I6-19S (b) A11-12H $\times$ I32-1S.

Table 5 Style morphs in progeny of crosses of distylous Turnera ulmifolia var. intermedia $(2 n=10)$ with three homstylous varieties $(2 n=30)$

\begin{tabular}{llll}
\hline & \multicolumn{3}{c}{ Style morphs of progeny } \\
\cline { 2 - 3 } Cross & Long & Short & Homostyle \\
\hline
\end{tabular}

(a) crosses with var. angustifolia

(i) Homostyle $\times$ Short

A11-12H $\times$ I32-1S

A11-12H $\times$ I6-19S

A11-12H $\times$ I6-31S

A11-14 $\times 132-1 \mathrm{~S}$

A11-14 $\mathrm{H} \times 16-19 \mathrm{~S}$

A5-28H $\times$ I32-1S

Deviation from $1 \mathrm{~S}: 1 \mathrm{H}$

Heterogeneity

$\begin{array}{ccr}0 & 54 & 46 \\ 0 & 17 & 14 \\ 0 & 11 & 18 \\ 0 & 10 & 3 \\ 0 & 7 & 9 \\ 0 & 3 & 5 \\ G=0 \cdot 25, P=0.62 & \\ G=7 \cdot 12, P=0 \cdot 21 & \end{array}$

(ii) Long $\times$ Homostyle

I6-12L $\times$ A $11-12 \mathrm{H}$

I6-12L $\times$ A1 1-14H

I6-12L $\times$ A17-1 H

(b) crosses with var. orientalis

$\begin{array}{cccc}\text { I6-12 } \mathrm{L} \times 01-21 \mathrm{H} & 0 & 0 & 80 \\ \text { O1-21 } \times \text { I6-19S } & 0 & 40 & 36 \\ \begin{array}{c}\text { Deviation from 1S: 1H } \\ G=0.21, P=0.65\end{array} & \end{array}$

(c) crosses with var. velutina

V1-3H $\times$ I32-1S

V1-3H $\times 16-19 \mathrm{~S}$

11-10L $\times$ V1-3H

(0)

$\begin{array}{lll}0 & 0 & 4 \\ 0 & 0 & 4 \\ 0 & 0 & 7\end{array}$

80

4

\section{DISCUSSION}

The genetic control of distyly was first elucidated by Bateson and Gregory (1905), although Darwin (1877) undertook the necessary crosses. In all cases, the syndrome of characters that comprises the polymorphism is controlled by a single gene locus with two alleles. Recently, Schou and Philip (1984) have identified a second genetic system where the floral polymorphism and incompatibility system are apparently uncoupled, and possibly controlled by unlinked loci. A similar system may operate in Narcissus (Dulberger, 1964). Evidence for supergene control of distyly has been obtained for species in the Primulaceae (Ernst, 1955) and Plumbaginaceae (Baker, 1966). Preliminary data is also available for the Rubiaceae (Baker, 1958). In Amsinckia spectablis of the Boraginaceae, Ganders (1979) has shown that homostylous phenotypes are not the result of recombination within a supergene. This does not exclude the possibility of supergene control of the polymorphism in this species, but indicates that genes other than those of the supergene are responsible for homostyle formation. Indeed, two such genes are known to occur in Primula sinensis (Mather, 1950).

The Turnera ulmifolia complex exhibits distyly, with reciprocal lengths of styles and stamens, pollen size dimorphism, and a strong self- and intramorph incompatibility system (Barrett, 1978). In 
diploids, we have shown that distyly is controlled by a single locus with two alleles. Long-styled plants are ss and short-styled plants can be either $S$ s or $S S$. However, homozygous shorts, although viable, will not generally occur in natural populations, as disassortative mating, enforced by diallelic incompatibility, will prevent their formation. In tetraploids of T. ulmifolia a similar pattern of inheritance is observed. Short-styled plants are of genotype Ssss and long-styled plants are ssss. A short-styled plant of genotype SSss was synthesised by colchicine doubling and presumably short-styled genotypes with 3-4 doses of the $S$ allele could be synthesised by the appropriate procedures.

A large deficiency in the number of short-styled progeny was obtained on selfing short-styled plants of the tetraploid T. ulmifolia var. elegans. This occurred in a self-compatible short-styled plant and two of its progeny. None of the three models considered gave a satisfactory fit to the data. We suggest that the aberrant ratios may be the result of the self-compatibility gene(s) imparting a selective advantage to male gametophytes of genotype ss. This hypothesis could be tested by performing the appropriate crosses. Aberrant ratios and their possible causes have been considered for other heterostylous taxa (Mather and de Winton, 1941; Baker, 1975; Weller and Ornduff, 1977; Ganders, 1979).

Casper and Charnov (1982) argue, based on sex allocation theory, that the $1: 1$ morph ratio found in most distylous populations is an evolutionary stable state. Further, under their model "autosomal" genes can cause the ratio to deviate from 1:1 given the appropriate selection pressures. In nine populations of $T$. ulmifolia var. elegans we found no evidence of deviation from a 1:1 morph ratio. In addition, progeny tests of 21 open-pollinated families revealed no deviation from $1: 1$, or heterogeneity among families. These data suggest that no significant genetic variation for morph ratio occurs within these populations of T. ulmifolia var. elegans, and isoplethy is a simple outcome of disassortative mating and Mendelian segregation at the distyly locus.

The three homostylous varieties of $T$. ulmifolia that we have studied experimentally are morphologically differentiated, allopatric, intersterile, and occur at different margins of the range of the species complex. This suggests that heterostyly has broken down to homostyly on at least three occasions in the species complex, always in association with the hexaploid condition (Shore and Barrett, 1985; and unpubl. data). All three varieties were used to determine the inheritance of homostyly and provide evidence for supergene control of distyly. Based on a hypothesis of supergene control of distyly we can predict (1) discrete phenotypic segregation and (2) specific dominance relationships of alleles governing control of the alternative floral phenotypes. Under the model we expect the following dominance relationships: $S>$ $h>s$, where $h$ is an allele determining homostyly. This pattern of dominance was observed for crosses involving all three varieties, although for var. velutina few progeny were raised. The clear segregation of floral phenotypes in the $F_{1}$ and pattern of dominance is consistent with the hypothesis that distyly is controlled by a supergene (composed of at least two loci) in T. ulmifolia.

The similar behaviour of homostylous varieties, in crosses with heterostylous populations, suggests that they have arisen via the same genetic mechanism involving recombination within the distyly supergene. Charlesworth and Charlesworth (1979a) modelled the breakdown of distyly and found that if the allele determining the short-styled morph is dominant, as in T. ulmifolia, long-homostyles are likely to spread to fixation with greater probability than other self-compatible phenotypes. Data from T. ulmifolia provide support for the model since each breakdown event has resulted in fixation of the long-homostyle phenotype.

In our surveys and experimental work of distylous populations in $T$. ulmifolia we have not observed the occurrence of homostylous plants. Mather (1950) proposed that the supergene controlling distyly in Primula might be contained within an inversion and as a result was protected from recombination. However, no firm evidence that such an inversion occurs in Primula species has been found and we have no cytological evidence for inversion polymorphisms in $T$. ulmifolia. De Winton and Haldane (1935) found no evidence for double reduction in $P$. sinensis and Dowrick (1956) detected a low frequency of occurrence in $P$. obconica. Since this may indicate that the distyly locus is linked to the centromere, Dowrick (1956) suggested that centromere interference might prevent crossing-over from occurring within the supergene of some Primula species.

We have demonstrated tetrasomic inheritance of distyly in tetraploid $T$. ulmifolia, however, we did not detect double reduction. The frequency of double reduction is an increasing function of the frequency of quadrivalent formation and recombination between the locus and centromere. Quadrivalent formation has been documented in tetraploid T. ulmifolia (Raman and Kesavan, 1964; 
Arbo and Fernandez, 1983; Shore and Barrett, unpublished data) and we estimate the frequency of quadrivalent formation to be about 50 per cent. If we assume that quadrivalents are distributed at random among all sets of homologous chromosomes and that the distyly locus is not linked to the centromere, then $a=0.07$, approximately (Allard, 1960). Hence, given the sample sizes used in our estimate of double reduction and the frequency of quadrivalent formation in $T$. ulmifolia, we cannot detect the effect of linkage to the centromere, if it occurs (the smallest $a$ we can detect is approximately 0.08 ). Thus, in addition to tight linkage among loci controlling distyly, centromere interference remains a tenable yet untested hypothesis for the apparent absence of recombinant homostyles in distylous populations of $T$. ulmifolia.

In T. ulmifolia there is an association between homostyly and hexaploidy. Cytological studies indicate that while all tetraploids form quadrivalents, and may be autopolyploids, the three hexaploid varieties form only bivalents at first metaphase, and are therefore likely to be allopolyploids (Shore and Barrett, unpublished data). In other heterostylous families, although there is a tendency for homostyly to occur at higher ploidy levels, no clear pattern emerges (Baker, 1966; Ockendon, 1968; Charlesworth and Charlesworth, $1979 b)$. Dowrick (1956) argued that chromosome doubling may change the position of chiasma formation and result in an increased frequency of recombination within the distyly supergene. This, however, does not explain why recombinant, polyploid, homostyles should preferentially spread through distylous populations following their origin. Several authors have modelled the spread of homostylous phenotypes in distylous populations (Crosby, 1949; Dowrick, 1956; Bodmer, 1960; Charlesworth and Charlesworth, 1979a). Current models of the evolution of selfing propose that inbreeding depression is the most important factor restricting the spread of selfers in outcrossing populations (Maynard Smith, 1978; Charlesworth and Charlesworth, 1979a; Lloyd, 1979; Lande and Schemske, 1985). It is possible that recombinant homostyles might spread more easily in hexaploid populations, as a result of a reduction in the magnitude of inbreeding depression associated with hexaploidy.

Acknowledgements Research funded by grants from the Natural Sciences and Engineering Research Council of Canada.

\section{REFERENCES}

AllaRD, R. W. 1960. Principles of Plant Breeding. John Wiley \& Sons, New York.

ARBo, M. M. AND FERNANIEZ, A. 1983. Posicion taxonomica, citologia y palinologia de tres niveles de ploidia de Turnera subulata Smith. Bonplandia, 5, 211-226.

BAKER, H. G. 1958. Studies in the reproductive biology of West African Rubiaceae. J. West African Sci. Assoc., 4, 9-24.

BAKER, H. G. 1966. The evolution, functioning and breakdown of heteromorphic incompatibility systems. I. The Plumbaginaceae. Evolution, 20, 349-368.

BAKER, H. G. 1975. Sporophyte-gametophyte interaction in Linum and other genera with heteromorphic incompatibility. In Mulcahy, D. L. (ed.) Gamete Competition in Plants and Animals. North Holland Publishing Co., Amsterdam, pp. 191-199.

BARRETT, S. C. H. 1978. Heterostyly in a tropical weed: the reproductive biology of the Turnera ulmifolia complex (Turneraceae). Can. J. Bot., 56, 1713-1725.

BATESON, W. AND GREGORY, R. P. 1905. On the inheritance of heterostylism in Primula. Proc. Roy. Soc. Lond. B., 76, 581-586.

BODMFR, W. F. 1960. The genetics of homostyly in populations of Primula vulgaris. Phil. Trans. Roy. Soc. Lond., 242, 517-549.

CASPER, B. B. AND CHARNOV, E. L. 1982. Sex allocation in heterostylous plants. J. Theoret. Biol., 96, 143-149.

CHARLESWORTH, B. AND CHARLESWORTH, D. 1979a. The maintenance and breakdown of distyly. Amer. Nat., 114, 499-513.

CHARleSWORTH, D. ANDCHARLESWORTH, B. 1979 b. A model for the evolution of distyly. Amer. Nat. 114, 467-498.

CROSBY, J. 1949. Selection of an unfavourable gene-complex. Evolution, 3, 212-230.

DARWIN, C. 1877. The Different Forms of Flowers on Plants of the Same Species. John Murray, London.

DE WINTON, D. AND HALIDANE, J. B. S. 1935. The genetics of Primula sinensis. J. Genet., 31, 67-100.

DOWRICK, V. P. J. 1956. Heterostyly and homostyly in Primula obconica. Heredity, 10, 219-236.

DULBERGER, R. 1964. Flower dimorphism and self-incompatibility of Narcissus tazetta L. Evolution, 18, 361-363.

ERNST, A. 1955. Self-fertility in monomorphic Primulas. Genetica, 27, 91-148.

GANDERS, F. R. 1975. Heterostyly, homostyly, and fecundity in Amsinckia spectabilis (Boraginaceae). Madroño, 56-62.

(GANIDERS, F. R. 1979. The biology of heterostyly. New Zeal. J. Bot., 17, 607-635.

LANDE, R. AND SCHEMSKE, D. W. 1985. The evolution of self-fertilization and inbreeding depression in plants. I. Genetic models. Evolution, 39, 24-40.

LLOYD, D. G. 1979. Some reproductive factors affecting the selection of self-fertilization in plants. Amer. Nat., 113, 67-79.

MATHER, K. 1950. The genetical architecture of heterostyly in Primula sinensis. Evolution, 4, 340-352.

MATHER, K. AND DE WINTON, D. 1941. Adaptation and counter-adaptation of the breeding system in Primula. Ann. Bot. N.S., 5, 297-311.

MAYNARD SM1TH, J. 1978. The Evolution of Sex. Cambridge University Press, Cambridge.

OCKENDON, D. H. 1968. Biosystematic studies in the Linum perenne group. New Phytol., 67, 787-813.

ORNDUFF, R. 1979. The genetics of heterostyly in Hypericum aegypticum. Heredity, 42, 271-272. 
RAMAN, V. S. AND KESAVAN. 1964. Meiosis and the nature of polyploidy in Turnera ulmifolia. .J. Indian Bot. Soc., 43, 495-497.

SCHOU, O. AND PHII.IP, M. 1984. An unusual heteromorphic incompatibility system 3 . On the genetic control of distyly and self-incompatibility in Anchusa officinalis $L$. (Boraginaceae). Theor. Appl. Genet., 68, 139-144.

SHORE, J. S. ANI) BARRETT, S. C. H. 1985. Morphological differentiation and crossability among populations of the Turnera ulmifolia L. complex (Turneraceae). Syst. Bot., (in press).
SOKAl, R. R. AND ROHLF, F. J. 1981. Biometry. W. H. Freeman and Company, San Francisco.

URBAN, I. 1883. Monographie de Familie der Turneracean. Berlin: Gebruder Borntraeger.

WELLER, S. G. AND ORNDUFF, R. 1977. Cryptic self-incompatibility in Amsinckia grandiflora. Evolution, 31, 47-51. 